Review

\title{
Environmental Impacts of Infrastructure Development under the Belt and Road Initiative
}

\author{
Hoong Chen Teo ${ }^{1}$, Alex Mark Lechner ${ }^{1,2, * \mathbb{D}}$, Grant W. Walton ${ }^{3}$, Faith Ka Shun Chan ${ }^{4}$, \\ Ali Cheshmehzangi ${ }^{5}$, May Tan-Mullins ${ }^{6}$, Hing Kai Chan ${ }^{7}$, Troy Sternberg ${ }^{8}$ and \\ Ahimsa Campos-Arceiz 1,2 (D) \\ 1 School of Environmental and Geographical Sciences, University of Nottingham Malaysia, \\ Semenyih 43500, Malaysia; hgyht1@nottingham.edu.my (H.C.T.); \\ Ahimsa.Camposarceiz@nottingham.edu.my (A.C.-A.) \\ 2 Mindset Interdisciplinary Centre for Environmental Studies, University of Nottingham Malaysia, \\ Semenyih 43500, Malaysia \\ 3 Development Policy Centre, Crawford School of Public Policy, Australia National University, \\ Camberra 2601, Australia; grant.walton@anu.edu.au \\ 4 School of Geographical Sciences, University of Nottingham Ningbo China, Ningbo 315100, China; \\ Faith.Chan@nottingham.edu.cn \\ 5 Department of Architecture and Built Environment, University of Nottingham Ningbo China, \\ Ningbo 315100, China; Ali.Cheshmehzangi@nottingham.edu.cn \\ 6 School of International Studies, University of Nottingham Ningbo China, Ningbo 315100, China; \\ May.TAN-MULLINS@nottingham.edu.cn \\ 7 Nottingham University Business School China, University of Nottingham Ningbo China, \\ Ningbo 315100, China; Hingkai.Chan@nottingham.edu.cn \\ 8 School of Geography, University of Oxford, Oxford OX1 3QY, UK; troy.sternberg@geog.ox.ac.uk \\ * Correspondence: Alex.Lechner@nottingham.edu.my
}

Received: 1 May 2019; Accepted: 14 June 2019; Published: 19 June 2019

\begin{abstract}
China's Belt and Road Initiative (BRI) is the largest infrastructure scheme in our lifetime, bringing unprecedented geopolitical and economic shifts far larger than previous rising powers. Concerns about its environmental impacts are legitimate and threaten to thwart China's ambitions, especially since there is little precedent for analysing and planning for environmental impacts of massive infrastructure development at the scale of BRI. In this paper, we review infrastructure development under BRI to characterise the nature and types of environmental impacts and demonstrate how social, economic and political factors can shape these impacts. We first address the ambiguity around how BRI is defined. Then we describe our interdisciplinary framework for considering the nature of its environmental impacts, showing how impacts interact and aggregate across multiple spatiotemporal scales creating cumulative impacts. We also propose a typology of BRI infrastructure, and describe how economic and socio-political drivers influence BRI infrastructure and the nature of its environmental impacts. Increasingly, environmental policies associated with BRI are being designed and implemented, although there are concerns about how these will translate effectively into practice. Planning and addressing environmental issues associated with the BRI is immensely complex and multi-scaled. Understanding BRI and its environment impacts is the first step for China and countries along the routes to ensure the assumed positive socio-economic impacts associated with BRI are sustainable.
\end{abstract}

Keywords: China; Belt and Road Initiative; BRI; One Belt One Road; infrastructure; environmental impacts; environmental impact assessment; transboundary conservation; silk road 


\section{Introduction}

China's "Going Out" strategy has culminated in what will be the largest infrastructure scheme in our lifetime - the Belt and Road Initiative (BRI; initially known as "One Belt One Road" or OBOR), announced by President Xi Jinping in 2013 [1]. The BRI comprises six overland and one maritime economic cooperation corridors, which are expected to connect around half of the world's population and over 60 countries [2]. Infrastructure projects are the most prominent component of BRI, which will feature various cooperation mechanisms under the "Five Connectivities" of policy, infrastructure, trade, finance and socio-cultural connectivity [3]. BRI has been heralded as a new phase of globalisation, which will integrate inland and maritime economies, unlike the previous phases of globalisation which were primarily maritime-based [4]. Consequently, it will carve out a Eurasian continental and maritime geostrategic realm for China [5]. Although BRI is trumpeted as fulfilling the Chinese dream of national revitalisation and the creation of a regional "community of common destiny" [4], it indubitably serves strategic and domestic goals, such as developing the Western and Central parts of China and creating overseas investment opportunities for state-owned enterprises [6].

Chinese BRI investments are projected to exceed $\$ 1$ trillion, dwarfing all previous geopolitically-motivated American and Soviet spending [7]. The economic effects of these investments are rapidly being seen. For instance, Liu et al. [8] found that BRI mechanisms have stimulated more Chinese outward investments to BRI countries than non-BRI countries. However, concerns about the environmental impacts of BRI are rife [9-12], which Chinese academics have recognised as a possible hindrance to China's BRI ambitions $[13,14]$. In response, four Chinese ministries released a circular "Guidance on Promoting Green Belt and Road" to all government departments in 2017, followed by another circular from the Ministry of Ecology and Environment entitled "Plan for Cooperation in Ecological and Environmental Protection for the Belt and Road Initiative" [15]. Since then, hundreds of papers have been published in Chinese academic journals on environmental law, policy and financing for BRI [16], mostly theoretical rather than empirical. The research on the environmental impacts of BRI especially in English language international peer-reviewed scientific journals is sparse. Given the importance of a scientific evidence-based approach, which the Chinese government and academics have also recognised [17], it is necessary to understand the environmental impacts of BRI as a prerequisite for effective policy-making which encourages environmental and social sustainability.

There is little precedent for addressing environmental impacts of massive infrastructure development at the scale of BRI. Most environmental research and policy on development impacts such as mining or dams or regional development is still confined along disciplinary lines and to specific sites, although there is increasingly an emphasis on adopting a systemic perspective [18], taking into account characteristics of complex and interconnected systems $[19,20]$ such as cumulative impacts $[21,22]$. For example, Chinese economists have attempted to model economic variables and national-level environmental indicators for BRI countries [23-25]. However, data is often lacking for most BRI routes, so far research has been focused on regions in China where data is available (e.g., [26]). China has recognised this and is pushing for 'big data' information-sharing platforms for BRI [13]. There is a need to assess the key social, political and environmental dimensions [27-29] of BRI impacts, whilst recognising the data limitations and methodological challenges inherent in reconciling the natural and social sciences [30].

In this paper, we review infrastructure development under BRI to characterise the nature and types of environmental impacts and demonstrate how social, economic and political factors can shape these impacts. Drawing on environmental and geographical approaches, our objectives are to: (1) define what BRI is and what makes an infrastructure project part of it, (2) define the different types of infrastructure development associated with BRI and the associated environmental impacts on different components of the Earth systems, (3) provide a typology of BRI infrastructure according to key impact dimensions, (4) describe the role of social and economic drivers on BRI's environmental impacts and sustainability policies and (5) provide a framework to characterise BRI's environmental impacts using an interdisciplinary and multi-scale approach. The paper aims to address some of the ambiguity 
regarding the nature and impacts of the BRI and lay the groundwork for further interdisciplinary study and planning on the BRI that accounts for the multi-scale nature of this trans-boundary initiative. This is critical as the impacts of BRI are likely to be felt for many generations after the construction and development of BRI projects are completed across the globe.

\section{What is BRI?}

BRI is driven primarily by infrastructure development along spatial corridors linking China with various regions of Eurasia, motivated by geostrategic and economic development priorities [11,31]. Infrastructure is often defined and constrained by geopolitics [32-34]. Through spatial linkages of people, goods, energy, and information, infrastructure can facilitate geopolitical aims such as conquest, competition or cooperation [35]. This infrastructure is supported by, and facilitates, other cooperation mechanisms such as policy coordination, trade, financial and socio-cultural linkages [3]. Other development programmes undertaken by other powers such as the US, Russia or Japan have been often geopolitically-motivated as well [36], but BRI differs from these investments by being spatially concentrated along corridors designed with the express aim of facilitating trans-Eurasian transport connectivity and integration with China. As such, the spatial dimensions of BRI impacts are more notable than other distributed forms of globalisation or development and thus need to be assessed as a whole rather than on a project by project basis.

A problem with much of the literature on the BRI is that the line between an infrastructure project funded by China and a BRI project per se is often unclear. Projects with Chinese assistance take many forms, such as investments, turnkey projects, technical cooperation, grants, aid and concessional loans, with varying degrees of involvement from different Chinese actors [37,38]. Although the term 'BRI' is often applied loosely to just about any Chinese project in BRI countries [39], here we consider BRI projects from a primarily spatial perspective as those supported by, or facilitating, clearly-defined infrastructure corridors linking BRI countries with China. Projects not explicitly connected to a BRI corridor in such a way are not considered to be BRI within this paper, regardless of financing or motivation. Some of these projects may have started as independent projects and were later recognised as BRI projects, but were located in those infrastructure corridors. Given our definition, Table 1 provides an example of the range of projects that have been characterised under the banner of BRI. 
Table 1. Examples and characteristics of infrastructure built for Belt and Road Initiative (BRI) for a range of BRI corridors.

\begin{tabular}{|c|c|c|c|c|c|c|c|c|c|}
\hline $\begin{array}{l}\text { Infrastructure } \\
\text { Type }\end{array}$ & Country & Route & Examples & Construction & Area (sq km) & $\begin{array}{l}\text { Total Length } \\
\quad(\mathrm{km})^{1}\end{array}$ & Intensity & Type $^{2}$ & Ref \\
\hline \multicolumn{10}{|l|}{ Transport } \\
\hline \multirow[t]{2}{*}{ Road } & Kazakhstan & New Eurasia Land Bridge & Western Europe-Western China Highway & 2008-2018 & 8445 & 8445 & Med & Linear & [40] \\
\hline & Cambodia & $\begin{array}{l}\text { China-Indochina Peninsula Economic } \\
\text { Corridor }\end{array}$ & Phnom Penh-Sihanoukville highway & $2019-2023$ & 190 & 190 & Med & Linear & {$[41]$} \\
\hline \multirow[t]{2}{*}{ Rail } & Kyrgyzstan & China-Central Asia-West Asia Corridor & Uzbekistan-Kyrgyzstan-China railway & ТВC & 250 & 500 & Low & Linear & [42] \\
\hline & $\begin{array}{l}\text { Laos, } \\
\text { Thailand }\end{array}$ & $\begin{array}{l}\text { China-Indochina Peninsula Economic } \\
\text { Corridor }\end{array}$ & $\begin{array}{l}\text { Kunming-Vientiane railway; } \\
\text { Vientiane-Bangkok high speed rail }\end{array}$ & $2015-2022$ & 908 & 1816 & Low & Linear & {$[43,44]$} \\
\hline & Pakistan & China-Pakistan Economic Corridor & Gwadar & 2019-2022 & 17.4 & 4.2 & Med & Nodal & [45] \\
\hline \multirow{3}{*}{ Seaport $^{3}$} & Kazakhstan & New Eurasia Land Bridge & Kuryk & 2017-2022 & 1 & 1 & Med & Nodal & [46] \\
\hline & Malaysia & $\begin{array}{l}\text { China-Indochina Peninsula Economic } \\
\text { Corridor }\end{array}$ & Malacca & 2014-2019 & 5.5 & 2.4 & Med & Nodal & [47] \\
\hline & Sri Lanka & Maritime Silk Road & Hambantota & 2008-2014 & 60.7 & 7.8 & Med & Nodal & [48] \\
\hline \multicolumn{10}{|l|}{ Energy } \\
\hline Power lines & Pakistan & China-Pakistan Economic Corridor & Matiari-Lahore, Matiari-Faisalabad & $2017-2021$ & 203 & 2030 & Low & Linear & [49] \\
\hline \multirow[t]{3}{*}{ Pipeline } & Mongolia & $\begin{array}{l}\text { China-Mongolia-Russia Economic } \\
\text { Corridor }\end{array}$ & Russia-Mongolia-China pipeline & ТВC & 500 & 1000 & Med & Linear & {$[50]$} \\
\hline & Central Asia & China-Central Asia-West Asia Corridor & $\begin{array}{c}\text { Pan-Central Asia pipeline: Kazakhstan, } \\
\text { Kyrgyzstan, Tajikistan, Turkmenistan, } \\
\text { Uzbekistan to China }\end{array}$ & 2008 & 920 & 1840 & Med & Linear & [51] \\
\hline & Myanmar & $\begin{array}{l}\text { Bangladesh-China-India-Myanmar } \\
\text { Economic Corridor }\end{array}$ & Kyaukpyu-Kunming pipeline & 2010-2017 & 385 & 770 & Med & Linear & [52] \\
\hline Coal plants & Tajikistan & China-Central Asia-West Asia Corridor & Dushanbe & 2012-2016 & 0.04 & 0.2 & High & Nodal & [53] \\
\hline Hydropower & Pakistan & China-Pakistan Economic Corridor & Diamer-Bhasha dam (Indus River) & 2011-2029 & 1200 & 140 & High & Nodal & [49] \\
\hline Wind farms & Pakistan & China-Pakistan Economic Corridor & Gharo, Jhimpir, Cacho & 2017 & 60 & 7.7 & Low & Nodal & [49] \\
\hline Solar farms & Pakistan & China-Pakistan Economic Corridor & Quaid-e-Azam Bahawalpur & 2014-2015 & 26 & 5.1 & Low & Nodal & [49] \\
\hline \multicolumn{10}{|l|}{ Economic } \\
\hline \multirow[t]{2}{*}{$\begin{array}{l}\text { Special Economic } \\
\text { zone }\end{array}$} & Kazakhstan & New Eurasia Land Bridge & $\begin{array}{l}\text { China-Kazakhstan Khorgos International } \\
\text { Border Cooperation Center }\end{array}$ & 2010 & 5.6 & 2.4 & Med & Concentrated & [54] \\
\hline & Pakistan & China-Pakistan Economic Corridor & Gwadar Free Trade Zone & 2016-2018 & 25 & 5 & Med & Concentrated & [55] \\
\hline
\end{tabular}

${ }^{1}$ Linear infrastructure impact area was estimated based on infrastructure type-A $1 \mathrm{~km}$-wide for road, $500 \mathrm{~m}$ wide band for rail and pipeline and $100 \mathrm{~m}$ for power lines. These values allow for comparisons between infrastructure, but cumulative impacts of infrastructure can vary between $10 \mathrm{~km}$ and $80 \mathrm{~km}$ or more and can even cross nations [56,57]; ${ }^{2}$ See Section 4.1 for a more detailed discussion on linear, nodal and concentrated typologies; ${ }^{3}$ Indicative values for area and length of impact derived from land-based footprint of port and associated developments. 


\section{Nature of BRI Environmental Impacts}

In this section, we define the different types of development associated with BRI and the range of environmental impacts associated with each development type. Environmental impacts of infrastructure projects are the product of interactions between the infrastructure and the receiving environment. Using an Earth systems approach [58,59], we characterised how different types of infrastructure development affect different components of the Earth systems: atmosphere, hydrosphere, geosphere and biosphere (Table 2). Land-use changes, landscape connectivity, and emissions are the primary impact pathways through which BRI infrastructure will impact a wide variety of natural systems across Eurasia, across various spatiotemporal scales. Although human activities already perturb most of Earth's ecosystems directly [60,61], when natural processes are disrupted to the extent that their inherent abilities to restore equilibrium are compromised-whether at the catchment level [62], at the planetary level [63], or anything in between-Earth systems risk being substantially and irreversibly destabilised. BRI infrastructure risks extending the human footprint into pristine regions and aggravating the existing footprints [10], destabilising Earth systems at various scales.

The Earth systems approach illustrates BRI environmental impacts at and between multiple scales. Atmospheric systems such as the East and South Asian monsoons [64] and the Central Asian dust storms [65] have complex teleconnections across the globe, but are closely coupled with human activities on land. For example, large-scale agricultural intensification and urbanisation in India were shown to cause a reduction in rainfall during the South Asian monsoon [66,67]. On continental belt routes, however, the degree of coupling between different spatial levels of the hydrosphere is weaker, so river systems are often studied at the catchment-scale or reach-scale [68]. BRI infrastructure will affect almost all of Eurasia's largest river systems, such as the Mekong [69], and may exacerbate water stress in regions like Central Asia [70]. The geosphere, comprising soils and rocks, serves as buffers, filters, sources and sinks, but has a finite carrying capacity often exceeded by human activities [71,72]. Additionally, many BRI routes such as the Karakoram Highway pass through geodynamically active areas, posing landslide risks [73]. Impacts on the biosphere, such as habitat degradation, fragmentation and loss, affect the health and survival of organisms and ecosystems [74,75]. Direct impacts give rise to a slew of secondary or indirect impacts. Apart from direct impacts, infrastructure development facilitates successive indirect effects like poaching, logging, settlement and other human invasions; it is thus imperative to "avoid the first cut", especially for pristine regions [76]. One such threat from BRI is the Russia-China Amur Bridge transport corridor, which dissects two nature reserves with old-growth forests [12]. Crucially, many environmental systems exhibit threshold behaviour, absorbing impacts before the threshold but destabilising rapidly once the threshold is exceeded, introducing additional uncertainty $[63,77]$. 
Table 2. A summarised review of key direct impacts associated with a range of infrastructure development.

\begin{tabular}{|c|c|c|c|c|c|}
\hline \multirow{2}{*}{ Infrastructure Type } & \multicolumn{4}{|c|}{ Impact on Earth Systems } & \multirow{2}{*}{ e.g., Ref } \\
\hline & Atmosphere & Hydrosphere & Geosphere & Biosphere & \\
\hline \multicolumn{6}{|l|}{ Transport } \\
\hline Road & $\begin{array}{l}\text { Air pollution; dust; microclimatic } \\
\text { effects from warming; noise }\end{array}$ & $\begin{array}{l}\text { Impede drainage; } \\
\text { pollution and sediments } \\
\text { in runoff; littering }\end{array}$ & $\begin{array}{l}\text { Soil erosion; landslides } \\
\text { especially in mountainous } \\
\text { terrain }\end{array}$ & $\begin{array}{c}\text { Habitat loss; edge and barrier effects, } \\
\text { particularly wider clearings; roadkills; } \\
\text { fragmentation; human and exotic species } \\
\text { invasions }\end{array}$ & {$[78,79]$} \\
\hline Rail & $\begin{array}{l}\text { Less local pollution as pollution } \\
\text { generated at power plant for } \\
\text { electric trains; noise }\end{array}$ & Contaminants in runoff & $\begin{array}{l}\text { Less than road but still } \\
\text { present; soil pollution }\end{array}$ & $\begin{array}{c}\text { Similar to roads, including fragmentation } \\
\text { and barrier effects. Generally, less severe } \\
\text { than roads; limited stops reduce human } \\
\text { footprint }\end{array}$ & {$[79,80]$} \\
\hline Airport & Air pollution; acid rain; noise & $\begin{array}{l}\text { Impede drainage; } \\
\text { chemical contaminants in } \\
\text { runoff; solid and } \\
\text { hazardous waste }\end{array}$ & Soil pollution & $\begin{array}{l}\text { Often affects floodplains, wetlands and } \\
\text { coasts; noise and light disturbance }\end{array}$ & [81-83] \\
\hline Seaport & $\begin{array}{l}\text { Local air pollution from ships and } \\
\text { refineries }\end{array}$ & $\begin{array}{l}\text { Direct discharge of } \\
\text { pollutants }\end{array}$ & Dredging and reclamation & $\begin{array}{l}\text { Exotic species invasions from ballast } \\
\text { discharge; algal blooms from nutrient } \\
\text { runoff; mortality from ship strikes and } \\
\text { entanglement in waste }\end{array}$ & {$[84,85]$} \\
\hline \multicolumn{6}{|l|}{ Energy } \\
\hline Pipelines & Air pollution; noise & $\begin{array}{l}\text { Contaminants in runoff; } \\
\text { risk of accidents }\end{array}$ & Soil pollution & $\begin{array}{l}\text { Habitat loss; fragmentation; human and } \\
\text { exotic species invasions }\end{array}$ & [86] \\
\hline Power lines & $\begin{array}{l}\text { Electromagnetic disturbance; } \\
\text { redistribution of pollution to power } \\
\text { source }\end{array}$ & $\begin{array}{l}\text { Contaminants in runoff } \\
\text { (mainly during } \\
\text { construction) }\end{array}$ & $\begin{array}{l}\text { Soil pollution, compaction } \\
\text { (mainly during } \\
\text { construction) }\end{array}$ & $\begin{array}{l}\text { Habitat loss; edge and barrier effects; } \\
\text { fragmentation; human and exotic species } \\
\text { invasions; avian/bat mortality }\end{array}$ & {$[87,88]$} \\
\hline Hydropower & $\begin{array}{l}\text { Heavy usage of energy-intensive } \\
\text { concrete, usually produced from } \\
\text { coal-fired plants; greenhouse gas } \\
\text { emissions from decomposing } \\
\text { biomass in reservoir }\end{array}$ & $\begin{array}{l}\text { Alteration of river flow } \\
\text { and sediment transport }\end{array}$ & $\begin{array}{l}\text { Higher water table affects } \\
\text { soil, can cause landslides } \\
\text { and soil erosion }\end{array}$ & $\begin{array}{c}\text { Hydrological changes affect aquatic } \\
\text { ecosystem; submersion of vast swathes } \\
\text { of forest }\end{array}$ & {$[89,90]$} \\
\hline
\end{tabular}


Table 2. Cont

\begin{tabular}{|c|c|c|c|c|c|}
\hline \multirow{2}{*}{ Infrastructure Type } & \multicolumn{4}{|c|}{ Impact on Earth Systems } & \multirow{2}{*}{ e.g., Ref } \\
\hline & Atmosphere & Hydrosphere & Geosphere & Biosphere & \\
\hline Coal plants & $\begin{array}{l}\text { Toxic air pollution; acid rain; } \\
\text { greenhouse gases }\end{array}$ & $\begin{array}{c}\text { Heavy metal } \\
\text { contamination; high water } \\
\text { usage; thermal pollution }\end{array}$ & $\begin{array}{l}\text { Subsidence from lowering } \\
\text { of water table }\end{array}$ & $\begin{array}{l}\text { Physical habitat destruction; air and } \\
\text { water pollutants }\end{array}$ & {$[91,92]$} \\
\hline Wind farms & \multicolumn{3}{|c|}{ Significantly lower impact than fossil fuel power plants, but will still have life-cycle impacts } & Avian/bat mortality & [93] \\
\hline Solar farms & $\begin{array}{l}\text { Thermal pollution and } \\
\text { microclimatic changes; glare effect }\end{array}$ & $\begin{array}{c}\text { Reduced infiltration } \\
\text { capacity due to shading of } \\
\text { soil, potentially increasing } \\
\text { runoff }\end{array}$ & $\begin{array}{l}\text { Soil sealing, shading and } \\
\text { degradation }\end{array}$ & $\begin{array}{l}\text { Landscape alteration and habitat } \\
\text { fragmentation }\end{array}$ & [94] \\
\hline \multicolumn{6}{|l|}{ Economic } \\
\hline $\begin{array}{l}\text { Special Economic } \\
\text { Zone }\end{array}$ & Air pollution; noise & $\begin{array}{l}\text { Impede } \\
\text { drainage-flooding risks; } \\
\text { pollution and sediments } \\
\text { in runoff }\end{array}$ & Soil erosion and pollution & $\begin{array}{l}\text { Habitat loss and fragmentation driven by } \\
\text { land cover change and urbanisation }\end{array}$ & {$[95,96]$} \\
\hline
\end{tabular}


Multiple direct and/or indirect impacts can aggregate and interact to produce cumulative impacts [21]. The cumulative impact dimension of BRI (Figure 1) is particularly significant because BRI will concentrate infrastructure and other economic activities along its routes, while also dispersing human activities to new or previously less accessible locations. While each direct impact can often be reductively studied within the confines of one discipline, human actors and actions play a key role in the cumulative dimension of impacts. Consequently, interdisciplinary cumulative impact modelling is fraught with challenges and has yet to be widely done even at a local scale, let alone continental-scale transformations like BRI [97].

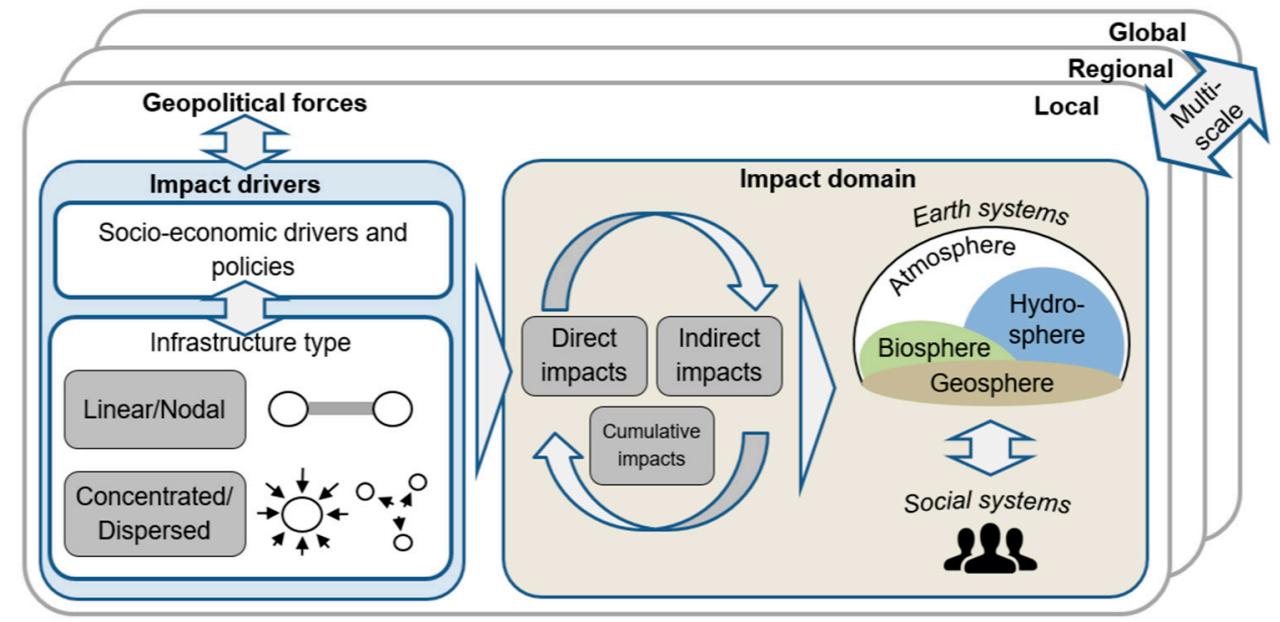

Figure 1. Multi-scale, socio-economic-political and environmental framework for planning and addressing the impacts of BRI.

Cumulative impacts occur at multiple temporal and spatial scales. For example, air pollution and anthropogenic climate forcing effects are determined by a confluence of factors, such as climate and topology, and have effects ranging from microclimatic changes to regional phenomena like smog when human activities are compounded. Substantial changes in the nature and spatial extent of human activity brought about by BRI will have regional climatic effects and teleconnections on a global scale. For example, Central Asian rangelands are carbon sinks of global importance [98], and there are concerns that increasing BRI-facilitated industrial activity will affect regional climate [99], but these are still poorly quantified.

Similarly, soil and hydrological conditions in BRI corridors interact with other Earth systems in response to human activity. These risks may sometimes be unavoidable. For example, the Karakoram Highway connecting Xinjiang, China to Gwadar Port, Pakistan passes through Himalayan regions known for "very high geodynamic activity" such as earthquakes, landslides, glacial erosion and unpredictable monsoons [73], but alternative routes are even more challenging. In the Aral Sea, Central Asia, cumulative impacts from the socio-environmental interactions between mis-management, over-irrigation and serious pollution causing water scarcity are magnified by "seriously dysfunctional" transboundary management which has the potential to result in armed conflicts [70].

\section{Typology of BRI Environmental Impact Drivers}

Characterising the drivers of environmental impacts requires an understanding of multi-scale, temporal and spatial characteristics of infrastructure development. Here, we attempt to provide a typology of BRI infrastructure according to function, causality, and spatiotemporal scale and intensity, in order to understand the features of BRI infrastructure which define and interact with the impact drivers and impact domain, especially through the context of the receiving environment. A key requirement for evidence-based strategic planning approaches and any form or modelling which attempts to project impacts into the future is a shared understanding of the dimensions of these impacts. 


\subsection{Function}

The function of BRI infrastructure determines its features, particularly its spatial footprint on the landscape and interactions with other impact drivers. The sub-discipline of transport geography sees infrastructure as mediating flows of people, goods, information and energy [100]; infrastructure imposes a structure on space across spatial scales spanning from local to global, determined by economic links and relations [35]. Economic systems structure space, which impacts the environment through the characteristics of the spatial footprint of infrastructure. Linear physical infrastructure, as frequently mentioned in environmental impact literature (e.g., Reference [75]), extends long distances across space to connect two places, while nodal infrastructure occupies a more focused area. Economic infrastructure such as free trade zones serve to concentrate economic activity, while certain development initiatives may serve to disperse economic activity [101,102]. The type and function of BRI infrastructure is shown in Table 3. It is important to note that certain kinds of infrastructure may occupy more than one category-for instance, a Liquefied Natural Gas (LNG) terminal might be considered as both a transport and energy infrastructure.

Table 3. Typology of BRI infrastructure according to type and function.

\begin{tabular}{|c|c|c|c|c|}
\hline Category & Type & Examples & $\begin{array}{l}\text { Primarily } \\
\text { Physical }\end{array}$ & Function \\
\hline Transport & Linear & Road, rail & Y & $\begin{array}{l}\text { Movement of people and goods } \\
\text { between settlements separated by space }\end{array}$ \\
\hline \multirow[b]{4}{*}{ Communication } & Nodal & $\begin{array}{l}\text { Airports, seaports, rail } \\
\text { terminal }\end{array}$ & Y & $\begin{array}{l}\text { Serve as land-sea, land-air, and } \\
\text { land-land interface }\end{array}$ \\
\hline & Linear & Pipelines, power lines & $\mathrm{Y}$ & Energy transmission across space \\
\hline & Nodal & $\begin{array}{l}\text { Dams, coal, wind, } \\
\text { solar, mines }\end{array}$ & $\mathrm{Y}$ & $\begin{array}{l}\text { Energy generation-convert energy } \\
\text { source into form suitable for human use }\end{array}$ \\
\hline & Linear & Fibre-optic cables & $Y^{*}$ & $\begin{array}{l}\text { Movement of information between } \\
\text { settlements separated by space }\end{array}$ \\
\hline \multirow{3}{*}{ Economic } & Nodal & Receiving stations & $Y^{*}$ & $\begin{array}{l}\text { Serve as network-network or } \\
\text { network-user interface }\end{array}$ \\
\hline & Concentrated & $\begin{array}{l}\text { Special Economic } \\
\text { Zones (SEZs) }\end{array}$ & $\mathrm{N}$ & $\begin{array}{l}\text { Concentrate economic activity in a } \\
\text { geographically-limited area }\end{array}$ \\
\hline & Dispersed & $\begin{array}{c}\text { Development } \\
\text { incentives, financial } \\
\text { mechanisms }\end{array}$ & $\mathrm{N}$ & $\begin{array}{c}\text { Facilitate economic activity across a } \\
\text { wider region }\end{array}$ \\
\hline
\end{tabular}

* Communication infrastructure is physical, but physical distance and location have a less pronounced effect on the network. Additionally, it has a smaller physical footprint and landscape impacts.

\subsection{Causality}

The wide-ranging scope of BRI projects, especially when spatially concentrated along corridors, bring about complex causal relationships and interactions between different infrastructure types. A simplified model of this is presented in Figure 2. Economic activities are dependent on physical infrastructures (especially transport and energy), and increase demand for them [103,104]. Communications infrastructure often plays an "invisible" supporting role but can also stimulate certain types of economic activity [105]. Other infrastructure which promotes economic activity, such as Special Economic Zones (SEZs; [105]), can also be very influential in shaping economic activities and interactions [106-108]. These interactions and causal relationships can be used to model possible BRI activities and thus their cumulative impacts. 


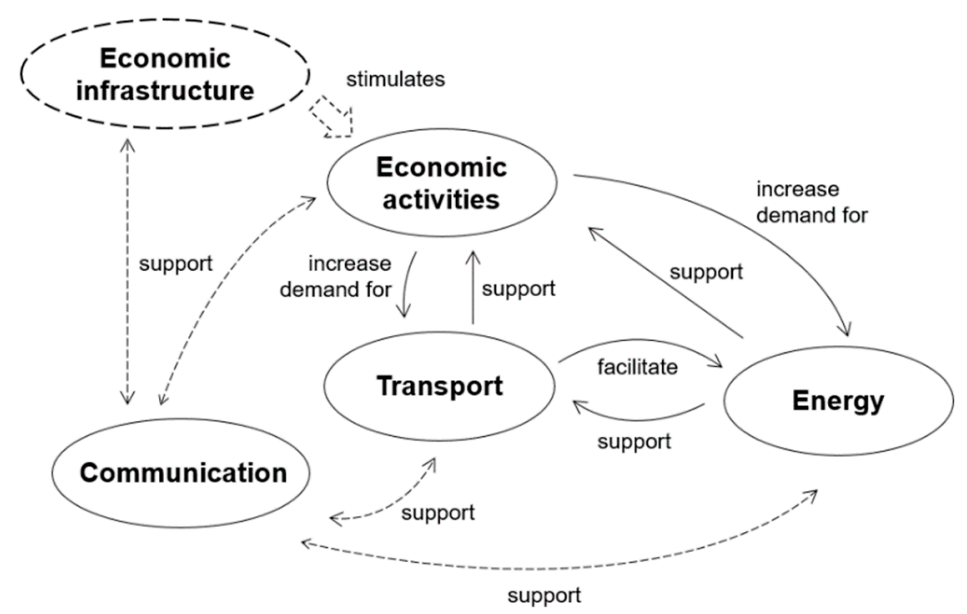

Figure 2. Relationships between different BRI infrastructure types. Plain arrows indicate causal relationships and dotted arrows indicate interactions.

\subsection{Scale and Intensity of BRI Impacts}

Infrastructure types differ in the manner in which they modify the landscape and thus create direct impacts. They also differ in how they create cumulative impacts by facilitating successive development and modifying the behaviour of other actors interacting with the landscape. Impacts can be considered as a function of immediate onsite footprint on the environment, which is the product of its total impact area and total impact intensity $[109,110]$, demonstrated in Figure 3 as a generalisation for each "typical" project type. Nodal infrastructure (such as airports and seaports, see Section 4.1) tends to be more spatially compact than linear infrastructure (such as roads) and tends to have a smaller total impact area. However, long-distance road and rail projects may still have a higher total impact intensity (i.e., disruption of Earth systems). Although there may not always be a choice between different infrastructure types, limited by contextually-specific constraints, an awareness of how different infrastructure types affect the environment differently can aid planning and mitigation efforts. Taking a risk-based approach, the temporal and probabilistic characteristics could also be considered. For example, oil spills from pipelines and tankers are infrequent but potentially very damaging events to their receiving environments as well as having severe economic impacts.

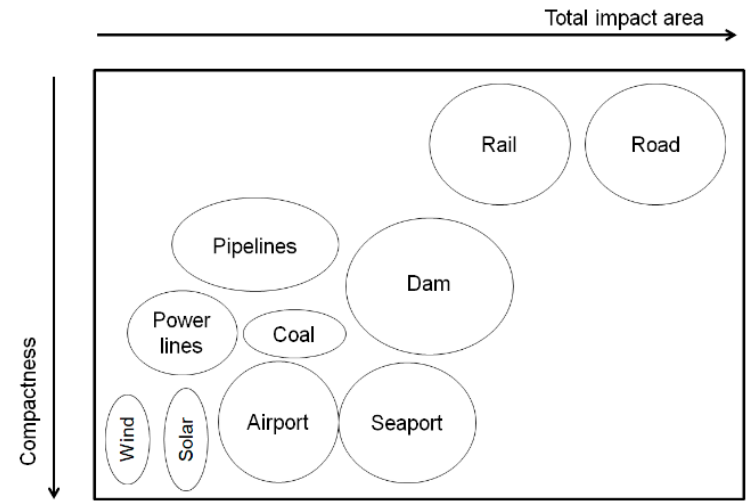

(a)

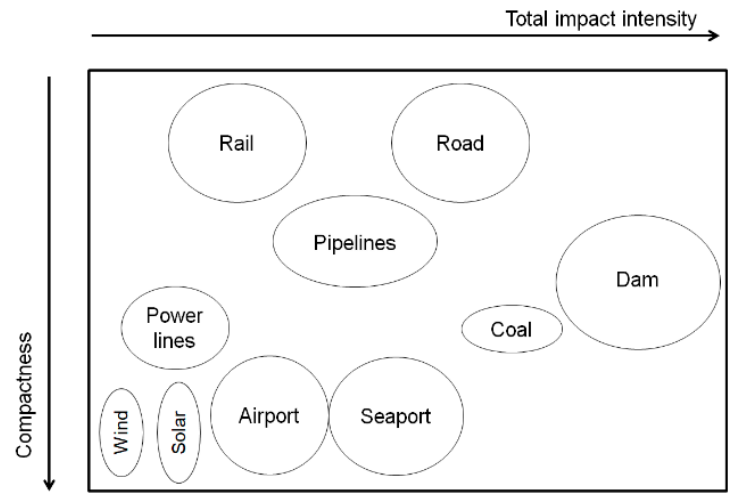

(b)

Figure 3. A simplified schematic describing (a) total impact area and (b) total impact intensity versus compactness of BRI infrastructure types.

A major infrastructure project often facilitates other development (Figure 4) and understanding the dynamics of this temporally sequential process can shed light on how different developments aggregate and interact over time to influence consequential impacts on the landscape. A large nodal project, such as a dam, requires a series of supporting developments such as concrete factories, 
settlements and road networks, and thus spurs the construction of more linear infrastructures across the landscape [76]. Alternatively, linear infrastructure may serve as a catalyst for nodal projects and more linear infrastructure to form networks. On a smaller scale this may take the form of transit-oriented developments [111]. For example, improved road and rail links between China and Kazakhstan, especially through the Khorgos border area, laid the groundwork for the China-Kazakhstan Khorgos SEZ [112]. Additionally, the Chinese-funded Karakoram Highway and Gwadar Port provide access to the Indian Ocean from Xinjiang. This improved transport connectivity has accelerated industrial development along the route $[113,114]$.

Scenario A: Large nodal infrastructure facilitates other development

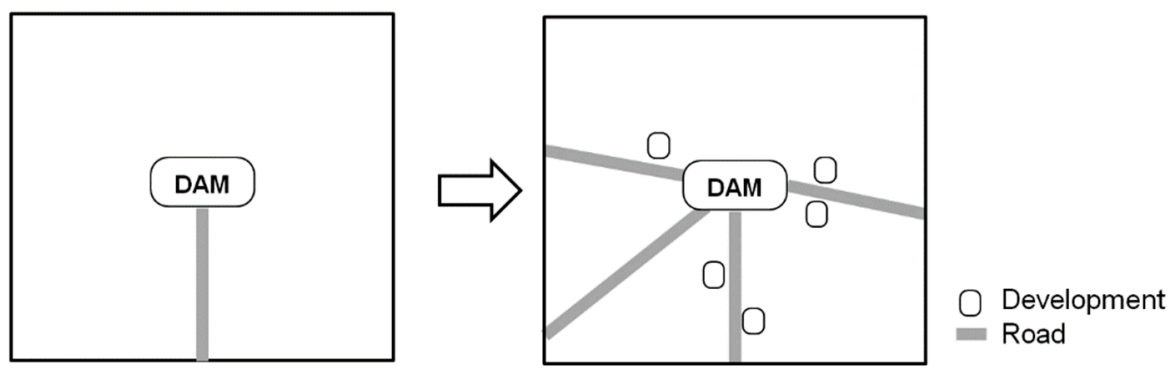

Scenario B: Linear infrastructure facilitates other development
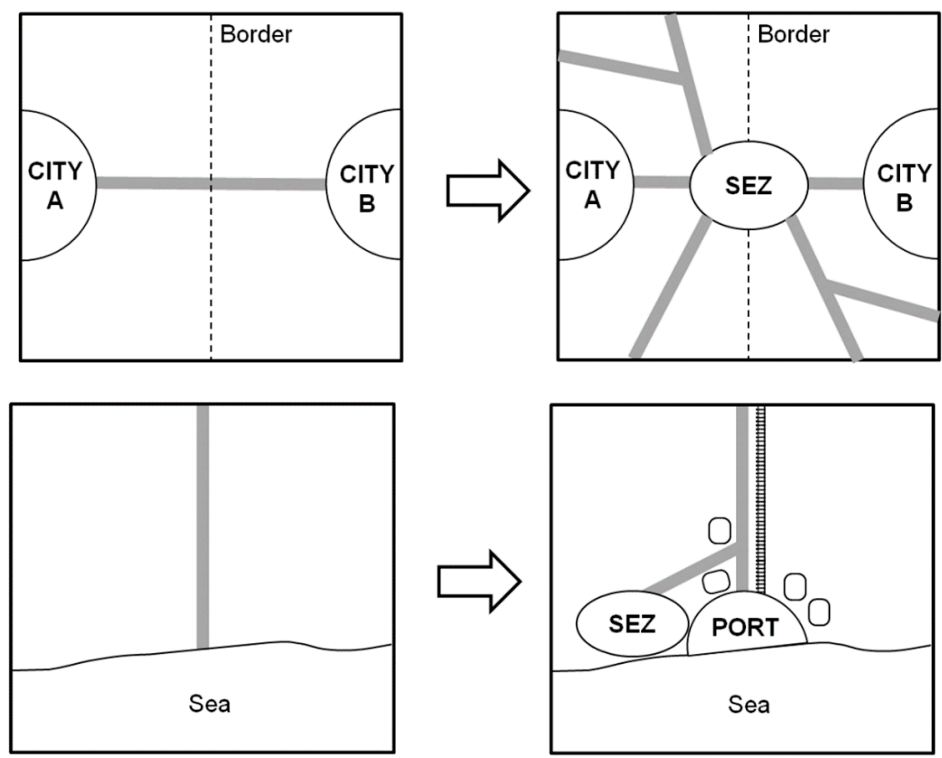

Development
Road
mail

Figure 4. Examples of temporal sequentiality of BRI infrastructure development.

\section{Economic Drivers and Environmental Impacts}

Having already discussed direct and indirect impacts and drivers (i.e., what is happening on the ground), in this section we examine economic drivers and benefits and relationship with environmental impacts. The economic benefits of BRI infrastructure are driven primarily by increased trade in goods, services and resources, facilitated by reduced transportation costs and other trade barriers. BRI is projected to increase total exports of 46 BRI countries by $\$ 5$ billion to $\$ 135$ billion and GDP by 0.3 to 1.4 percent [2]. However, reduced trade barriers can cause jurisdictions with lax environmental regulations to gain a comparative advantage, redistributing environmental impacts [115]. There are fears that as trade barriers are lowered, China's tightening environmental regulations may make many BRI countries more attractive as pollution havens, a process which BRI may accelerate [116]. Heavily-polluting Chinese cement plants relocating to Tajikistan has been cited as one example of 
this [117]. Additionally, a logging moratorium in China's Heilongjiang province caused spill-over effects for forests abroad [12]. The extent to which this may be a problem has been questioned by empirical evidence from the economic literature which suggests that only marginal firms relocate, while most remain and comply with stricter laws [118]. In addition, trade-related changes in industrial composition may facilitate production at lower relative emission intensities $[119,120]$. Suggesting an interplay of these factors, an econometric study found evidence for the pollution haven effect in BRI countries from non-Chinese investment but found that Chinese investment reduced emissions [121].

Trade also transforms techniques of production and consumption, changing income and thus pollution levels [122]. According to the environmental Kuznets curve, pollution increases initially as income grows, but above a turning point, pollution falls as higher incomes bring technological improvements and increasing demand for environmental amenities. Although the evidence and theory behind the environmental Kuznets curve is highly contentious [123-126], evidence suggests that environmental policies, clean technology and economic liberalisation can help to flatten the Kuznets curve $[127,128]$.

Production techniques can improve through mechanisms such as technology transfer and trade-induced innovation. Although China is the world's largest $\mathrm{CO}_{2}$ emitter [129], increases in research activity, technological advancement and the assimilation of foreign technology have played a role in abating Chinese $\mathrm{CO}_{2}$ emissions [130]. Additionally, China is also the world's largest investor in renewables, and high levels of Chinese investment and production have reduced the costs of renewable energy infrastructure [131]. By 2020, all Chinese coal plants will be more efficient and less pollutive than every US coal plant [132]. BRI can facilitate overseas transfer of Chinese technology, with concomitant environmental benefits [133]. China has upgraded Tajikistani and Kyrgyzstani coal plants with newer technology $[53,134]$, and signed deals to upgrade Bangladeshi coal mines, power grids and factories [135].

Economic growth may increase the industrial pollution base, known as scale effects [136]. Negative scale effects and positive technique effects on the environment are difficult to isolate empirically, and quantitative studies disagree on whether the scale or technique effect is larger [137,138]. Different pollutants also react differently to trade-related changes. For example, a Chinese study combining scale and technique effects suggested that trade increased $\mathrm{SO}_{2}$ and dust fall but reduced chemical oxygen demand, arsenic and cadmium [139]. This underscores the need for interdisciplinary studies combining the macroeconomic perspective with the spatial and contextual nuance of environmental science.

\section{Socio-Political Drivers and Environmental Policies}

As outlined above, BRI may cause foreseeable environmental impacts at a range of scales and intensities. Actors associated with multiple social, administrative and political scales (from the local to the global) will play a key role in moderating these environmental impacts [140]. While not the focus of this paper, the social impacts of development considered through social impact assessments alongside environmental impact assessments can have long-term negative effects on local communities [141]. Social drivers identify factors that contribute to and mediate environmental impacts, such as community structures and institutions, people's preferences, behaviour and capacity to influence change [142]. Chinese companies' past record of alleged forced evictions and environmental degradation $[143,144]$ suggest that without local accountability the BRI is likely to face local resistance. Concerns about environments, communities and livelihoods can galvanise civil society into action. In Kyrgyzstan, for example, locals burnt down a BRI-supported Chinese gold-processing plant after their fears of pollution were not sufficiently addressed [145]. Fears of local backlash and Chinese political pressure can motivate Chinese corporations to take corporate social responsibility (CSR) more seriously with recognition of community concerns. For example, China Road and Bridge Corporation (CRBC) opened its procurement process for the Mombasa-Nairobi standard gauge railway to local contractors instead of using only Chinese contractors, and consulted with wildlife experts to enable animals to cross the 
railway line safely [146]. However, social drivers of BRI environmental impacts are not limited only to China and host countries. US and EU consumers are responsible for $30 \%$ of the carbon emissions in BRI countries through embodied carbon flows [147].

The dominant role of the state in China means that its intents and actions are central to any socio-political discussions and policies, and directly affect social drivers [148]. Crucially, Chinese political will to think long-term on strategic issues recognises environmental problems as a threat. Since the 'ecological civilisation' concept was added to the constitution in 2012, it has featured prominently in Chinese discourse regarding the environment and formulation of environmental policies [149]. Widespread dissatisfaction about environmental degradation has led policy makers to strengthen environmental regulations $[149,150]$. China has also sought to improve environmental governance frameworks and to engage stakeholders in resolving environmental conflicts and disputes. For example, Quanzhou municipality set up an ecological compensation scheme for the Jin River catchment in Fujian province. Downstream areas compensated upstream villages and local governments for taking measures to conserve the catchment [151]. Encouragingly, local and state governments in China are working to coordinate environmental policies at larger scales to resolve inter-jurisdictional environmental issues [152]. There have been similar calls to develop ecological compensation frameworks for BRI [153]. China's newfound concern for the environment is notable but benefits in BRI host countries remain to be seen.

Although intended primarily for economic development, BRI mechanisms can provide a platform for China and partner countries to promote cross-boundary environmental conservation and environmental management [10]. This is urgently needed as BRI countries are already responsible for $95 \%$ of global net embodied carbon exports [147]. Partly in response to foreign pressure, China has outlined its policies to promote green development and environmental protection for BRI [154]. This builds on the idea of a Green BRI described previously in a document co-issued by government officials describing the promotion of green energy, sustainable agriculture, aquaculture and forestry [155].

Guidelines also exist for specific areas that are relevant to BRI, some of which were developed prior to BRI. Two documents on forestry provide guidance on environmental protection (e.g., avoiding soil erosion, minimising noise and air pollution), and biodiversity conservation (e.g., conserving habitats, protecting threatened species, enhancing sustainable forestry, etc.) for the Chinese enterprises to integrate with environmental legislation and operations in host countries [156,157]. Other Chinese and international documents provide more detailed country-specific recommendations [158]. These guidelines suggest China's attempts to promote sustainable trade and green economy at the international level [154]. These include calls for expanding cooperation with international agencies, governments and non-governmental organisations around the environmental impacts of BRI [159].

However, some scholars and commentators are concerned that these policies will fail to translate into practice. Potential problems include serious concerns about enforcing China's environmental regulations across multiple jurisdictions and scales as many environmental policies directed towards China's overseas investment are already non-binding [160]. Mechanisms rely upon host countries laws to evaluate Chinese companies' conduct yet enforcement is often weak [160]. Moreover, local regulations and standards may be lower than those found in China (see also $[9,161]$ ) or have different agendas [162]. Often, limited information sharing between China and host countries hampers transnational enforcement efforts [160]. For Tracy et al. [12] the disjuncture between Chinese policy and host countries' poor environmental records means the BRI is an environmental 'race to the bottom'.

Secondly, there are gaps in the application of China's environmental policy. Most guidelines for environmental protection in foreign investment and cooperation target China's large state-owned enterprises (SOEs). This overlooks the impact of private companies, particularly small and medium enterprises (SMEs) [163]. SOEs will lead BRI initiatives over SMEs [40] yet private sector organisations from China and elsewhere still play a key role $[164,165]$. It is these firms that are often responsible for serious environmental degradation because SMEs are not as strictly regulated [161]. There remain 
questions about how China's environmental policies compare to international standards. A coalition of organisations led by the Green Finance Initiative [166] argues that projects deemed to be 'green' by Chinese Catalogue standards may not be considered green by international guidelines.

In summary, while China has been developing environmental policies around the BRI, questions remain as to how effective they will be. China stresses the improved economic value and global infrastructure associated with the BRI, yet unequal power relationships between Chinese and host nations along the road can cause contestation between sides. Too often misunderstanding in local communities that shoulder the burden of debt, degradation, corruption and displacement accompany BRI projects [167-169]. The challenge for China is to construct an integrative rather than exploitative BRI-one that is inclusive of host nations, provides beneficial infrastructure and outcomes, protects the environment, and is done in such a way that China's intent and reputation remains intact.

\section{Conclusions: Planning for the BRI}

Planning and addressing environmental issues associated with the BRI is immensely complex and multi-scaled. This paper defined BRI and the dimensions of its impacts and drivers. We did this by proposing a typology of BRI infrastructure, describing the range of impacts on different components of the Earth system and the economic and socio-political drivers which influence BRI development and impacts. In addition, we provided a multi-scale, socio-economic-political and environmental framework for planning and addressing the impacts of BRI.

Understanding the characteristics of impacts of BRI infrastructure on the environment is the first step for devising policy and plans for addressing its impacts to ensure sustainable development. The scale of its impacts may appear overwhelming and, given this, there is a tendency to address BRI in a piecemeal fashion at the project scale or with broad brushstrokes by examining the initiative in its entirety. However, the cumulative impacts that occur both regionally and globally mean we cannot take such an approach, particularly if standardised and not context-specific. A multi-scale approach is required ensuring that BRI is considered at the project scale through an environmental impact assessment, at the regional scale through strategic environmental assessments, then at the ecoregion scale (e.g., Central Asia; South East Asia coral reef triangle) and finally at the global scale. Recent guidelines on the BRI (see References $[154,159]$ ) have emphasised the importance of multi-scaled approaches to implementing the BRI, but have provided little detail about what this means in practice. Policy makers in China and recipient countries should find the interdisciplinary multi-scale analysis presented in this paper useful in debates about how the ecological and social impacts of BRI might be understood and managed.

The implications of BRI go even further, by spurring on other major powers to develop their own global schemes. For example, India's alternative is an economic corridor to Russia through Iran and Central Asia [170], while Russia is integrating Central Asian economies with the Eurasian Economic Union [171]. Meanwhile, Japanese influence is still strong, with Japan outspending China on road and railway projects in six Southeast Asian countries [172]. It is important that BRI provides a role model for dealing with environmental impacts in order to raise the bar for future global infrastructure development programs and ensure that leading practice environmental standards form an integral part of any global infrastructure scheme.

Author Contributions: The manuscript was conceptualized and written by H.C.T. and A.M.L. All other authors contributed to the writing, editing and reviewing the paper.

Funding: This research received no external funding.

Conflicts of Interest: The authors declare no conflict of interest. 


\section{References}

1. China MFA. President Xi Jinping Delivers Important Speech and Proposes to Build a Silk Road Economic Belt with Central Asian Countries. 7 September 2013. Available online: http://www.fmprc.gov.cn/mfa_eng/ topics_665678/xjpfwzysiesgjtfhshzzfh_665686/t1076334.shtml (accessed on 16 May 2019).

2. Villafuerte, J.; Corong, E.; Zhuang, J. The One Belt, One Road Initiative Impact on Trade and Growth. In Proceedings of the 19th Annual Conference on Global Economic Analysis, Purdue University, Washington, DC, USA, 15-17 June 2016; Available online: https://www.gtap.agecon.purdue.edu (accessed on 10 June 2019).

3. Summers, T. China's 'New Silk Roads': Sub-national regions and networks of global political economy. Third World Q. 2016, 37, 1628-1643. [CrossRef]

4. Zheng, B. China's “One Belt, One Road” Plan Marks the Next Phase of Globalization. New Perspect. Q. 2017, 34, 27-30.

5. Brewster, D. Silk Roads and Strings of Pearls: The Strategic Geography of China's New Pathways in the Indian Ocean. Geopolitics 2017, 22, 269-291. [CrossRef]

6. Ferdinand, P. Westward ho-The China dream and 'one belt, one road': Chinese foreign policy under Xi Jinping. Int. Aff. 2016, 92, 941-957. [CrossRef]

7. Shambaugh, D. China's Soft-Power Push. Foreign Aff. 2015, 99, 99-107.

8. Liu, H.Y.; Tang, Y.K.; Chen, X.L.; Poznanska, J. The Determinants of Chinese Outward FDI in Countries Along “One Belt One Road”. Emerg. Mark. Finance Trade 2017, 53, 1374-1387. [CrossRef]

9. Ascensão, F.; Fahrig, L.; Clevenger, A.P.; Corlett, R.T.; Jaeger, J.A.G.; Laurance, W.F.; Pereira, H.M. Environmental challenges for the Belt and Road Initiative. Nat. Sustain. 2018, 1, 206-209. [CrossRef]

10. Lechner, A.M.; Chan, F.K.S.; Campos-Arceiz, A. Biodiversity conservation should be a core value of China's Belt and Road Initiative. Nat. Ecol. Evol. 2018, 2, 408-409. [CrossRef]

11. Sternberg, T.; Ahearn, A.; Mcconnell, F. Central Asian 'Characteristics' on China's New Silk Road: The Role of Landscape and the Politics of Infrastructure. Land 2017, 6, 55. [CrossRef]

12. Tracy, E.F.; Shvarts, E.; Simonov, E.; Babenko, M. China's new Eurasian ambitions: The environmental risks of the Silk Road Economic Belt. Eur. Geogr. Econ. 2017, 58, 56-88. [CrossRef]

13. Chen, $X$. Yong lvse fazhan jiang "yidaiyilu" jiancheng mingyun gongtongti [Using green development to make One Belt One Road a regional community of common destiny]. Reg. Econ. Rev. 2015, 6, 7-9.

14. Zhang, M. "Yidaiyilu” jianshe zhong ruhe shijian lvse fazhan linian? [How to implement green development concepts in One Belt One Road construction]. Reg. Econ. Rev. 2017, 6, 5-7.

15. Cheng, C.; Weng, Z.; Ge, C.; Duan, Y. Promoting efficient multi-dimensional ecological and environmental cooperation to build a green Belt and Road. Environ. Prot. 2017, 45, 53-56.

16. Tao, H.; Yang, X.; Zhu, Q.; Hou, C.; Ma, S.; Wang, Q.; Jin, X. Wenxian jiliang fenxifa jingzhun dingwei ziyuan huanjinglei keji qikan "yidaiyilu" zhuanti cehua fangxiang [Special selection of Belt and Road Initiative for resource and environment scientific journals based on bibliometric analysis]. Chin. J. Sci. Tech. Period. 2018, 5, 520-524.

17. Deng, H. Tuijin lvse "yidaiyilu" jianshe de jidian sikao [Points of note in promoting a green OBOR]. Reg. Econ. Rev. 2017, 6, 10-11.

18. Virapongse, A.; Brooks, S.; Metcalf, E.C.; Zedalis, M.; Gosz, J.; Kliskey, A.; Alessa, L. A social-ecological systems approach for environmental management. J. Environ. Manag. 2016, 178, 83-91. [CrossRef] [PubMed]

19. Hamilton, S.H.; ElSawah, S.; Guillaume, J.H.A.; Jakeman, A.J.; Pierce, S.A. Integrated assessment and modelling: Overview and synthesis of salient dimensions. Environ. Model. Softw. 2015, 64, $215-229$. [CrossRef]

20. Jakeman, A.J.; Letcher, R.A. Integrated assessment and modelling: Features, principles and examples for catchment management. Environ. Model. Softw. 2003, 18, 491-501. [CrossRef]

21. Franks, D.M.; Brereton, D.; Moran, C.J. The cumulative dimensions of impact in resource regions. Resour. Policy 2013, 38, 640-647. [CrossRef]

22. Wang, Z.; Lechner, A.M.; Baumgartl, T. Mapping cumulative impacts of mining on sediment retention ecosystem service in an Australian mining region. Int. J. Sustain. Dev. World 2018, 25, 69-80. [CrossRef] 
23. Li, P.; Zhang, X.M. Sichou zhilu jingjidai ziyuan huanjing chengben ji shengtai fuhe qiangdu de shikong yanbian fenxi [Analysis of the spatial and temporal evolution about environmental cost and ecological load intensity of Silk Road Economic Belt]. Chin. J. Environ. Manag. 2017, 9, 69-77.

24. Wang, J.S. "Yidaiyilu" yanxian guojia lvse fazhan shuiping yanjiu [Research on green development level of countries along "the Belt and Road"]. J. Environ. Manag. Coll. China 2018, 28, 23-26. [CrossRef] [PubMed]

25. Liu, Y.Y.; Hao, Y. The dynamic links between $\mathrm{CO}_{2}$ emissions, energy consumption and economic development in the countries along "the Belt and Road". Sci. Total Environ. 2018, 645, 674-683. [CrossRef] [PubMed]

26. Zhang, Z.F.; He, W.J.; An, M.; Degefu, D.M.; Yuan, L.; Wu, X. Water security assessment of China's One Belt and One Road region. Water 2019, 11, 607. [CrossRef]

27. Folke, C.; Biggs, R.; Norström, A.V.; Reyers, B.; Rockström, J. Social-ecological resilience and biosphere-based sustainability science. Ecol. Soc. 2016, 21. [CrossRef]

28. McGinnis, M.D.; Ostrom, E. Social-ecological system framework: Initial changes and continuing challenges. Ecol. Soc. 2014, 19, 30. [CrossRef]

29. Ostrom, E. A General Framework for Analyzing Sustainability of Social-Ecological Systems. Science 2009, 325, 419-422. [CrossRef] [PubMed]

30. Bolongesi, T.; Gerlak, A.K.; Giuliani, G. Explaining and Measuring Social-Ecological Pathways: The Case of Global Changes and Water Security. Sustainability 2018, 10, 4378.

31. Yu, H. Motivation behind China's 'One Belt, One Road' Initiatives and Establishment of the Asian Infrastructure Investment Bank. J. Contemp. China 2017, 26, 353-368. [CrossRef]

32. Akhter, M. The Geopolitics of Infrastructure: Development, Expertise, and Nation on the Indus Rivers. University of Arizona, 2013. Available online: https://arizona.openrepository.com/handle/10150/311357 (accessed on 16 May 2019).

33. Bouzarovski, S.; Bradshaw, M.; Wochnik, A. Making territory through infrastructure: The governance of natural gas transit in Europe. Geoforum 2015, 64, 217-228. [CrossRef]

34. van der Putten, F.P. Infrastructure and geopolitics: China's emerging presence in the eastern mediterranean. J. Balk. Near East. Stud. 2016, 18, 337-351. [CrossRef]

35. Rodrigue, J.-P.; Comtois, C.; Slack, B. The Geography of Transport Systems, 4th ed.; Routledge: Oxford, UK, 2006.

36. Roberts, G. Moscow and the Marshall plan: Politics, ideology and the onset of the cold war, 1947. Eur. Asia Stud. 1994, 46, 1371-1386. [CrossRef]

37. Bräutigam, D. Aid 'With Chinese Characteristics': Chinese Foreign Aid and Development Finance Meet the OECD-DAC Aid Regime. J. Int. Dev. 2011, 23, 752-764. [CrossRef]

38. Tan-Mullins, M.; Urban, F.; Mang, G. Evaluating the Behaviour of Chinese Stakeholders Engaged in Large Hydropower Projects in Asia and Africa. China Q. 2017, 230, 464-488. [CrossRef]

39. Rolland, N. China's "Belt and Road Initiative": Underwhelming or Game-Changer? Wash. Q. 2017, 40, 127-142. [CrossRef]

40. Shepard, W. The Western Europe-Western China Highway Is Coming Alive in Kazakhstan. Forbes. 3 August 2016. Available online: https://www.forbes.com/sites/wadeshepard/2016/08/03/the-western-europe-westernchina-highway-is-coming-alive-in-kazakhstan/ (accessed on 16 May 2019).

41. Pisei, H. Sihanoukville Highway Work to Begin. The Phnom Penh Post. 5 March 2019. Available online: https://www.phnompenhpost.com/business-post-property/sihanoukville-highway-work-begin (accessed on 16 May 2019).

42. Pannier, B. No Stops in Kyrgyzstan For China-Uzbekistan Railway Line. Radio Free Europe. 3 September 2017. Available online: https://www.rferl.org/a/qishloq-ovozi-kyrgyzstan-uzbekistan-china-railway/28713485.html (accessed on 16 May 2019).

43. Mahitthirook, A. Bangkok Set to be China's Rail Hub. Bangkok Post. 28 December 2015. Available online: https://www.bangkokpost.com/news/general/808364/bangkok-set-to-be-china-rail-hub (accessed on 16 May 2019).

44. XINHUA. First Phase of Thai-Chinese High Speed Rail Project Approved by Thai Cabinet. XINHUA. 11 July 2017. Available online: http://news.xinhuanet.com/english/2017-07/11/c_136435964.htm (accessed on 16 May 2019).

45. Ahmed, K. Pakistan PM to Launch $\$ 230 \mathrm{~m}$ Gwadar Airport Project. Arab News. 28 March 2019. Available online: http://www.arabnews.com/node/1474206/world (accessed on 16 May 2019). 
46. Gupta, R.; Orlovskiy, E. Kazakhstan and the New Silk Road. PwC. 2017. Available online: https://www.pwc. kz/en/publications/new-2017/silk-way-publication-eng.pdf (accessed on 16 May 2019).

47. Jaipragas, B. Can China Really Deliver Malaysia's Singapore Slayer? South China Morning Post. 15 April 2017. Available online: http://www.scmp.com/week-asia/politics/article/2087402/can-china-really-delivermalaysias-singapore-slayer (accessed on 16 May 2019).

48. Sirilal, R.; Aneez, S. Sri Lanka Signs \$1.1 Billion China Port Deal Amid Local, Foreign Concerns. Reuters. 29 July 2017. Available online: https://www.reuters.com/article/us-sri-lanka-china-ports-idUSKBN1AE0CN?il=0 (accessed on 16 May 2019).

49. CPEC Energy Priority Projects. Available online: http://cpec.gov.pk/energy (accessed on 16 May 2019).

50. Otgonsuren, B. Mongolia-China-Russia Economic Corridor Infrastructure Cooperation. Erina Rep. 2015, 127. Available online: https://www.erina.or.jp/wp-content/uploads/2015/02/se12710_tssc.pdf (accessed on 16 May 2019).

51. Chen, X.; Fazilov, F. Re-centering Central Asia: China's “New Great Game” in the old Eurasian Heartland. Palgrave Commun. 2018, 4, 71. [CrossRef]

52. Cao, S.; Shan, J. Sino-Myanmar Oil Pipeline Launch a Good Signal: Experts. Global Times. 18 March 2017. Available online: http://www.globaltimes.cn/content/1039861.shtml (accessed on 16 May 2019).

53. AFP. China Completes $\$ 350$ Million Power Plant in Tajikistan's Capital Dushanbe. The Economic Times. 9 December 2016. Available online: https://energy.economictimes.indiatimes.com/news/power/chinacompletes-350-million-power-plant-in-tajikistan/55886095 (accessed on 16 May 2019).

54. Wong, S.L.; Gordeyeva, M. Silk Road Hub or Tax Haven? Reuters. 5 June 2017. Available online: https://www.reuters.com/article/us-china-silkroad-horgos/silk-road-hub-or-tax-haven-chinas-newborder-trade-zone-may-be-less-than-it-seems-idUSKBN18V15Z (accessed on 16 May 2019).

55. CPEC. Development of Free Zone. Available online: http://cpec.gov.pk/project-details/36 (accessed on 16 May 2019).

56. Laurance, W.F.; Sloan, S.; Weng, L.; Sayer, J.A. Estimating the Environmental Costs of Africa's Massive “Development Corridors". Curr. Biol. 2015, 25, 3202-3208. [CrossRef]

57. Siciliano, G.; Urban, F.; Tan-Mullins, M.; Mohan, G. Large dams, energy justice and the divergence between international, national and local developmental needs and priorities in the global South. Energy Res. Soc. Sci. 2018, 41, 199-209. [CrossRef]

58. Canepa, E.; Builtjes, P.J.H. Thoughts on Earth System Modeling: From global to regional scale. Earth Sci. Rev. 2017, 171, 456-462. [CrossRef]

59. Steffen, W.; Leinfelder, R.; Zalasiewicz, J.; Waters, C.N.; Williams, M.; Summerhayes, C.; Schellnhuber, H.J. Stratigraphic and Earth System approaches to defining the Anthropocene. Earth's Future 2016, 4, 324-345. [CrossRef]

60. Venter, O.; Sanderson, E.W.; Magrach, A.; Allan, J.R.; Beher, J.; Jones, K.R.; Watson, J.E.M. Sixteen years of change in the global terrestrial human footprint and implications for biodiversity conservation. Nat. Commun. 2016, 7, 1-11. [CrossRef] [PubMed]

61. Vitousek, P.M.; Mooney, H.A.; Lubchenco, J.; Melillo, J.M. Human Domination of Earth's Ecosystems. Science 1997, 277, 494-499. [CrossRef]

62. Leopold, L.B. A Reverence for Rivers. Berkeley, CA, USA. 1977. Available online: http://riogranderestoration. org/manager/download_files/15.pdf (accessed on 16 May 2019).

63. Rockström, J.; Steffen, W.; Noone, K.; Persson, Å.; Chapin, F.S.I.; Lambin, E.; Foley, J. Planetary Boundaries: Exploring the Safe Operating Space for Humanity. Ecol. Soc. 2009, 14, 32. [CrossRef]

64. Wang, B.; Wu, R.G.; Lau, K.-M. Interannual Variability of the Asian Summer Monsoon: Contrasts between the Indian and the Western North Pacific-East Asian Monsoons. J. Clim. 2001, 14, 4073-4090. [CrossRef]

65. Indoitu, R.; Orlovsky, L.; Orlovsky, N. Dust storms in Central Asia: Spatial and temporal variations. J. Arid Environ. 2012, 85, 62-70. [CrossRef]

66. Kishtawal, C.M.; Niyogi, D.; Tewari, M.; Pielke, R.A.; Shepherd, J.M. Urbanization signature in the observed heavy rainfall climatology over India. Int. J. Climatol. 2010, 30, 1908-1916. [CrossRef]

67. Niyogi, D.; Kishtawal, C.; Tripathi, S.; Govindaraju, R.S. Observational evidence that agricultural intensification and land use change may be reducing the Indian summer monsoon rainfall. Water Resour. Res. 2010, 46. [CrossRef] 
68. Jencso, K.G.; McGlynn, B.L.; Gooseff, M.N.; Wondzell, S.M.; Bencala, K.E.; Marshall, L.A. Hydrologic connectivity between landscapes and streams: Transferring reach- and plot-scale understanding to the catchment scale. Water Resour. Res. 2009, 45. [CrossRef]

69. Wang, Y.; Lin, Z. Jiaqiang dameigonghe ciquyu huanjing baohu hezuo wei "Yidaiyilu" zhanlve tigong huanbao zhicheng [Strengthening environmental cooperation in the Greater Mekong sub-region to support the One Belt One Road strategy]. Environ. Sustain. Dev. 2015, 2, 9-12.

70. Howard, K.W.F.; Howard, K.K. The new "Silk Road Economic Belt" as a threat to the sustainable management of Central Asia's transboundary water resources. Environ. Earth. Sci. 2016, 75, 1-12. [CrossRef]

71. Grieve, I.C. Human impacts on soil properties and their implications for the sensitivity of soil systems in Scotland. CATENA 2001, 42, 361-374. [CrossRef]

72. Norra, S.; Stüben, D. Urban Soils. J. Soils Sediments 2003, 3, 230-233. [CrossRef]

73. Derbyshire, E.; Fort, M.; Owen, L.A. Geomorphological hazards along the Karakoram highway: Khunjerab pass to the Gilgit river, Northernmost Pakistan. Erdkunde 2001, 55, 49-71. [CrossRef]

74. Johnstone, C.P.; Lill, A.; Reina, R.D. Habitat loss, fragmentation and degradation effects on small mammals: Analysis with conditional inference tree statistical modelling. Biol. Conserv. 2014, 176, 80-98. [CrossRef]

75. Laurance, W.F.; Goosem, M.; Laurance, S.G.W. Impacts of roads and linear clearings on tropical forests. Trends Ecol. Evol. 2009, 24, 659-669. [CrossRef] [PubMed]

76. Laurance, W.F.; Peletier-Jellema, A.; Geenen, B.; Koster, H.; Verweij, P.; Van Kuijk, M. Reducing the global environmental impacts of rapid infrastructure expansion. Curr. Biol. 2015, 25, R259-R262. [CrossRef]

77. Zehe, E.; Sivapalan, M. Threshold behaviour in hydrological systems as (human) geo-ecosystems: Manifestations, controls, implications. Hydrol. Earth Syst. Sci. 2009, 13, 1273-1297. [CrossRef]

78. Karlson, M.; Mörtberg, U.; Balfors, B. Road ecology in environmental impact assessment. Environ. Impact Assess. 2014, 48, 10-19. [CrossRef]

79. Laurance, W.F.; Balmford, A. Land use: A global map for road building. Nature 2013, 495, 308-309. [CrossRef]

80. Nokelaynen, T.S. Mapping of the environmental impacts of railway transport in Russia. InterCarto InterGIS 2016, 22, 256-261. [CrossRef]

81. Ashford, N.J.; Mumayiz, S.A.; Wright, P.H. Airport Engineering: Planning, Design and Development of 21st Century Airports, 4th ed.; John Wiley \& Sons: Hoboken, NJ, USA, 2011.

82. Kurniawan, J.S.; Khardi, S. Comparison of methodologies estimating emissions of aircraft pollutants, environmental impact assessment around airports. Environ. Impact Assess. 2011, 31, 240-252. [CrossRef]

83. Nunes, L.M.; Zhu, Y.-G.; Stigter, T.Y.; Monteiro, J.P.; Teixeira, M.R. Environmental impacts on soil and groundwater at airports: Origin, contaminants of concern and environmental risks. J. Environ. Monit. 2011, 13, 3026-3039. [CrossRef] [PubMed]

84. Puig, M.; Michail, A.; Wooldridge, C.; Darbra, R.M. Benchmark dynamics in the environmental performance of ports. Mar. Pollut. Bull. 2017, 121, 111-119. [CrossRef] [PubMed]

85. Trozzi, C.; Vaccaro, R. Environmental Impact of Port Activities. WIT Trans. Built Environ. 2000, 51, $151-161$.

86. Milt, A.W.; Gagnolet, T.; Armsworth, P.R. Synergies and Tradeoffs Among Environmental Impacts Under Conservation Planning of Shale Gas Surface Infrastructure. Environ. Manag. 2016, 57, 21-30. [CrossRef] [PubMed]

87. Biasotto, L.D.; Kindel, A. Power lines and impacts on biodiversity: A systematic review. Environ. Impact Assess. 2018, 71, 110-119. [CrossRef]

88. Jiang, Y.Z.; An, J.T.; Hong, J.E.; Zhao, R.X.; Li, F.W. Tegaoya shudian gongcheng daqi huanjing xiaoyi fenxi [Assessment methods for atmospheric environmental benefits of Ultra High Voltage power transmission projects]. Shandong Electr. Power 2016, 6, 5-10.

89. Fearnside, P.M. Environmental and Social Impacts of Hydroelectric Dams in Brazilian Amazonia: Implications for the Aluminum Industry. World Dev. 2016, 77, 48-65. [CrossRef]

90. Wang, Q.G.; Du, Y.H.; Su, Y.; Chen, K.Q. Environmental Impact Post-Assessment of Dam and Reservoir Projects: A Review. Procedia Environ. Sci. 2012, 13, 1439-1443. [CrossRef]

91. Munawer, M.E. Human health and environmental impacts of coal combustion and post-combustion wastes. J. Sust. Min. 2017, 17, 87-96. [CrossRef]

92. Thopil, G.A.; Pouris, A. A 20 year forecast of water usage in electricity generation for South Africa amidst water scarce conditions. Renew. Sust. Energy Rev. 2016, 62, 1106-1121. [CrossRef]

93. Jaber, S. Environmental Impacts of Wind Energy. J. Clean Energy Technol. 2014, 1, 251-254. [CrossRef] 
94. Delfanti, L.; Colantoni, A.; Recanatesi, F.; Bencardino, M.; Sateriano, A.; Zambon, I.; Salvati, L. Solar plants, environmental degradation and local socioeconomic contexts: A case study in a Mediterranean country. Environ. Impact Assess. 2016, 61, 88-93. [CrossRef]

95. Acbarpur, D. Assessment of environmental impact as a result of industrial development in the Pars special economic energy zone. Principy Èkol. 2014, 3, 25-41.

96. Chen, Y.; Zhang, Z.; Du, S.Q.; Shi, P.J.; Tao, F.L.; Doyle, M. Water quality changes in the world's first special economic zone, Shenzhen, China. Water Resour. Res. 2011, 47. [CrossRef]

97. Lechner, A.M.; McIntyre, N.; Witt, K.; Raymond, C.M.; Arnold, S.; Scott, M.; Rifkin, W. Challenges of integrated modelling in mining regions to address social, environmental and economic impacts. Environ. Model. Softw. 2017, 93, 268-281. [CrossRef]

98. Lal, R.; Suleimenov, M.; Stewart, B.A.; Hansen, D.O.; Doraiswamy, P. (Eds.) Climate Change and Terrestrial Carbon Sequestration in Central Asia; Taylor \& Francis: London, UK, 2007.

99. Gong, Z.; Peng, D.; Wen, J.; Cai, Z.; Wang, T.; Hu, Y.; Xu, J. Research on trend of warm-humid climate in Central Asia. IOP Conf. Ser. Earth Environ. Sci. 2017, 74. [CrossRef]

100. Keeling, D.J. Transportation geography: New directions on well-worn trails. Prog. Hum. Geogr. 2007, 31, 217-225. [CrossRef]

101. He, C.; Wei, Y.D.; Xie, X. Globalization, Institutional Change, and Industrial Location: Economic Transition and Industrial Concentration in China. Reg. Stud. 2008, 42, 923-945. [CrossRef]

102. Sjöberg, Ö.; Sjöholm, F. Trade Liberalization and the Geography of Production: Agglomeration, Concentration, and Dispersal in Indonesia's Manufacturing Industry. Econ. Geogr. 2009, 80, 287-310. [CrossRef]

103. Röller, L.-H.; Waverman, L. Telecommunications Infrastructure and Economic Development: A Simultaneous Approach. Am. Econ. Rev. 2001, 91, 909-923. [CrossRef]

104. Skorobogatova, O.; Kuzmina-Merlino, I. Transport Infrastructure Development Performance. Procedia Eng. 2017, 178, 319-329. [CrossRef]

105. Hackler, D. Invisible Infrastructure and the City. Am. Behav. Sci. 2003, 46, 1034-1055. [CrossRef]

106. Fourie, J. Economic infrastructure: A review of definitions, theory and empirics. S. Afr. J. Econ. 2006, 74, 530-556. [CrossRef]

107. Crane, B.; Albrecht, C.; Duffin, K.M.; Albrecht, C. China's special economic zones: An analysis of policy to reduce regional disparities. Reg. Stud. Reg. Sci. 2018, 5, 98-107. [CrossRef]

108. Tan-Mullins, M. The Environmental Implications of Chinese State-owned Enterprises (CSOEs) investment in Africa's energy sector. Int. J. Energy Secur. Environ. Res. 2014, 1, 43-58.

109. Chertow, M.R. The IPAT Equation and Its Variants. J. Ind. Ecol. 2000, 4, 13-29. [CrossRef]

110. Waggoner, P.E.; Ausubel, J.H. A framework for sustainability science: A renovated IPAT identity. Proc. Natl. Acad. Sci. USA 2002, 99, 7860-7865. [CrossRef]

111. Cervero, R. Transit-Oriented Development in the United States: Experiences, Challenges, and Prospects; The National Academic Press: Washington, DC, USA, 2004.

112. Wang, Y. Huoerguosi zai sichouzhilu jingjidai "Zhong-ha jingi zoulang" jianshe zhong fahui hulian hutong zuoyong de youshi tuxian [The connectivity advantages of Khorgos in the China-Kazakhstan economic corridor of the Silk Road Economic Belt]. New Silk Road Horizon 2016, 8, 44-47.

113. Wang, L. Zhong-ba jingji zoulang jianshe shiru kuaichedao [China-Pakistan economic corridor construction enters the fast lane]. New Silk Road Horizon 2014, 8, 82.

114. Xu, J.; Chen, K.; Yang, S.; Lin, Y. "Yidaiyilu” jiaotong jichu jianshe de guoji jingmaoxiao [International trade effects of One Belt One Road transport infrastructure]. Asia Pac. Econ. Rev. 2016, 3, 3-11.

115. Cole, M.A.; Elliott, R.J.R. Determining the trade-environment composition effect: The role of capital, labor and environmental regulations. J. Environ. Econ. Manag. 2003, 46, 363-383. [CrossRef]

116. Dong, Z.; Ge, C.; Wang, J.; Yan, X.; Cheng, C. "Yidaiyilu" lvse fazhan de zhanlve shishi kuangjia [Strategic framework for green development of OBOR]. Chin. J. Environ. Manag. 2016, 2, 31-35.

117. van der Kley, D. China Shifts Polluting Cement to Tajikistan. China Dialogue. 8 August 2016. Available online: https://www.chinadialogue.net/article/show/single/en/9174-China-shifts-polluting-cementto-Tajikistan (accessed on 16 May 2019).

118. Levinson, A.; Taylor, M.S. Unmasking the pollution haven effect. Int. Econ. Rev. 2008, 49, 223-254. [CrossRef]

119. Cherniwchan, J. Trade liberalization and the environment: Evidence from NAFTA and U.S. manufacturing. J. Int. Econ. 2017, 105, 130-149. [CrossRef] 
120. Saunders, C.; Barber, A.; Taylor, G. Food Miles—Comparative Energy/Emissions Performance of New Zealand's Agriculture Industry; Agribusiness \& Economics Research Unit, Lincoln University: Christchurch, New Zealand, 2006; Volume 295, Available online: https://hdl.handle.net/10182/125 (accessed on 16 May 2019).

121. Liu, N.Q.; Dai, J. Woguodui "yidaiyilu" yanxian guojia OFDI de huanjing [Empirical analysis on the environmental effects of China's OFDI to countries along "The Belt and Road". Bus. Manag. J. 2017, 39, 6-23.

122. Frankel, J.A.; Romer, D. Does trade cause growth? Am. Econ. Rev. 1999, 89, 379-399. [CrossRef]

123. Allard, A.; Takman, J.; Uddin, G.S.; Ahmed, A. The N-shaped environmental Kuznets curve: An empirical evaluation using a panel quantile regression approach. Environ. Sci. Pollut. Res. Int. 2018, 25, 5848-5861. [CrossRef]

124. Bo, S. A Literature Survey on Environmental Kuznets Curve. Energy Procedia 2011, 5, 1322-1325. [CrossRef]

125. Dinda, S. Environmental Kuznets Curve Hypothesis: A Survey. Ecol. Econ. 2004, 49, 431-455. [CrossRef]

126. Stern, D.I. The Rise and Fall of the Environmental Kuznets Curve. World Dev. 2004, 32, 1419-1439. [CrossRef]

127. Dasgupta, S.; Laplante, B.; Wang, H.; Wheeler, D. Confronting the Environmental Kuznets Curve. J. Econ. Perspect. 2002, 16, 147-168. [CrossRef]

128. Panayotou, T. Demystifying the environmental Kuznets curve: Turning a black box into a policy tool. Environ. Dev. Econ. 1997, 2, 465-484. [CrossRef]

129. European Commission. $\mathrm{CO}_{2}$ Time Series 1990-2015 Per Region/Country. Available online: http://edgar.jrc.ec. europa.eu/overview.php?v=CO2ts1990-2015 (accessed on 16 May 2019).

130. Ang, J.B. $\mathrm{CO}_{2}$ emissions, research and technology transfer in China. Ecol. Econ. 2009, 68, $2658-2665$. [CrossRef]

131. McCrone, A. Global Trends in Renewable Energy Investment 2017. Frankfurt. Available online: http://fs-unepcentre.org/sites/default/files/publications/globaltrendsinrenewableenergyinvestment2017.pdf (accessed on 16 May 2019).

132. Hart, M.; Bassett, L.; Johnson, B. Research Note on U.S. and Chinese Coal-Fired Power Data and Emissions. Center for American Progress, 2017. Available online: https://www.americanprogress.org/issues/green/ reports/2017/05/15/432136/research-note-u-s-chinese-coal-fired-power-data/ (accessed on 16 May 2019).

133. Shi, X. "Yidaiyilu" beijing xia de zhongguo keji "zouchuqu" zhanlve [Chinese technology "going out" in the context of One Belt One Road]. Theor. Res. 2017, 2, 41-46.

134. Levina, M. China Helps Upgrade Bishkek Thermal Power Plant. The Times of Central Asia. 23 September 2013. Available online: https://www.timesca.com/index.php/news/8295-china-helps-upgrade-bishkek-thermalpower-plant (accessed on 16 May 2019).

135. Awasthi, D. Bangladesh's Increased Commitment to China Helps It Land Deals Beyond OBOR. Frontera. 22 May 2017. Available online: https://frontera.net/news/asia/bangladesh-has-chosen-the-obor-on-its-pathto-success-and-china-is-responding/\# (accessed on 16 May 2019).

136. Grossman, G.; Krueger, A. Environmental Impacts of a North American Free Trade Agreement (No. 3914). Cambridge, MA, USA. 2019. Available online: https://doi.org/10.3386/w3914 (accessed on 16 May 2019).

137. Antweiler, W.; Copeland, B.R.; Taylor, M.S. Is Free Trade Good for the Environment? Am. Econ. Rev. 2001, 91, 877-908. [CrossRef]

138. Cole, M.A. Does trade liberalization increase national energy use? Econ. Lett. 2006, 92, 108-112. [CrossRef]

139. Shen, J. Trade liberalization and environmental degradation in China. Appl. Econ. 2008, 40, 997-1004. [CrossRef]

140. Guttman, D.; Young, O.; Jing, Y.; Bramble, B.; Bu, M.; Chen, C.; Zeidan, R. Environmental governance in China: Interactions between the state and "nonstate actors". J. Environ. Manag. 2018, 220, 126-135. [CrossRef]

141. Vanclay, F.; Esteves, A.M.; Aucamp, I.; Franks, D.M. Social Impact Assessment: Guidance for assessing and managing the social impacts of projects. Int. Assoc. Impact Assess. 2015, 1, 98. Available online: https://www.iaia.org/uploads/pdf/SIA_Guidance_Document_IAIA.pdf (accessed on 16 May 2019).

142. Dugarova, E.; Utting, P. Social Drivers of Sustainable Development. Geneva, Switzerland, 2013. Available online: http://www.unrisd.org/social-drivers-note (accessed on 16 May 2019).

143. Eisenman, J.; Stewart, D.T. China's New Silk Road Is Getting Muddy. Foreign Policy. 9 January 2017. Available online: https://foreignpolicy.com/2017/01/09/chinas-new-silk-road-is-getting-muddy/ (accessed on 16 May 2019). 
144. Yao, Y.; Zhang, Y. Public Perception of Chinese Investment in Myanmar and its Political Consequences: A Survey Experimental Approach. Policy Brief, International Growth Centre, 2018. Available online: https: //www.theigc.org/wp-content/uploads/2018/06/Yao-Zhang-2018-Policy-Brief.pdf (accessed on 16 May 2019).

145. Levina, M. Kyrgyzstan: China Demands to Protect Investor After Locals Burnt Gold-Processing Plant. The Times of Central Asia. 13 April 2018. Available online: https://www.timesca.com/index.php/news/ 19611-kyrgyzstan-china-demands-to-protect-investor-after-locals-burnt-gold-processing-plant (accessed on 16 May 2019).

146. KCETA. 2017 Chinese Enterprises in Kenya Social Responsibility Report; Kenya China Economic and Trade Association: Nairobi, Kenya, 2017. Available online: http://ke2.mofcom.gov.cn/17en.pdf (accessed on 16 May 2019).

147. Han, M.Y.; Yao, Q.H.; Liu, W.D.; Dunford, M. Tracking embodied carbon flows in the Belt and Road regions. J. Geogr. Sci. 2018, 28, 1263-1274. [CrossRef]

148. Zheng, S.; Kahn, M.E.; Sun, W.; Luo, D. Incentives for China's urban mayors to mitigate pollution externalities: The role of the central government and public environmentalism. Reg. Sci. Urban Econ. 2014, 47, 61-71. [CrossRef]

149. Chen, W.Y.; Hua, J. Citizens' distrust of government and their protest responses in a contingent valuation study of urban heritage trees in Guangzhou, China. J. Environ. Manag. 2015, 155, 40-48. [CrossRef] [PubMed]

150. Steinhardt, H.C.; Wu, F. In the Name of the Public: Environmental Protest and the Changing Landscape of Popular Contention in China. China J. 2016, 75, 61-82. [CrossRef]

151. Wang, X.; Berman, E.M.; Chen, D.; Niu, X. Strategies to improve environmental networks for pollution control: Evidence from eco-compensation programs in China. J. Environ. Manag. 2019, 234, 387-395. [CrossRef] [PubMed]

152. Chen, B.; Suo, L.; Ma, J. A Network Approach to Interprovincial Agreements. State Local Gov. Rev. 2015, 47, 181-191. [CrossRef]

153. Liu, R.J. "Yidaiyilu" zhong de shengtai buchang yanjiu zhongshu yu zhanwang [Review of ecological compensation in "One Belt and One Road"]. J. Anhui Adm. Inst. 2017, 4, 79-83.

154. China MEP. Guidance on Promoting Green Belt and Road. 2017. Available online: https://eng.yidaiyilu.gov. cn/qwyw/rdxw/12484.htm (accessed on 16 May 2019).

155. China MOFCOM. Tuidong Gongjian Sichouzhilu Jingjidai he 21 Shiji Haishang Sichouzhilu de Yuanjing [Vision and Actions on Jointly Building Silk Road Economic Belt and 21st-Century Maritime Silk Road]. Ministry of Commerce: Beijing, China, 2015. Available online: http://www.mofcom.gov.cn/article/i/dxfw/ jlyd/201601/20160101243342.shtml (accessed on 16 May 2019).

156. China MOFCOM. Zhongguo Qiye Jingwai Kechixu Senlin Peiyv Zhinan [A Guide on Sustainable Overseas Silviculture by Chinese Enterprises]. State Forestry Administration and Ministry of Commerce: Beijing, China, 2007. Available online: http://www.mofcom.gov.cn/aarticle/b/g/200712/20071205265858.html (accessed on 16 May 2019).

157. China MOFCOM. Zhongguo Qiye Jingwai Senlin Kechixu Jingying Liyong Zhinan [A Guide on Sustainable Overseas Forest Management and Utilization by Chinese Enterprises]. State Forestry Administration and Ministry of Commerce: Beijing, China, 2009. Available online: http://www.mofcom.gov.cn/aarticle/b/g/ 200904/20090406191363.html (accessed on 16 May 2019).

158. Chen, Y.; Muianga, M.; Chen, S.; Li, M. Manual on Sustainable Overseas Forest Management Trade and Investment by Chinese Enterprises: Mozambique Version. 2016. Available online: http://pubs.iied.org/ G04146/ (accessed on 16 May 2019).

159. China MEP. The Belt and Road Ecological and Environmental Cooperation Plan. 2017. Available online: https://eng.yidaiyilu.gov.cn/zchj/qwfb/13392.htm (accessed on 16 May 2019).

160. Zhu, R. Understanding China's Overseas Investments Governance and Analysis of Environmental and Social Policies. Global Environmental Institute, 2015. Available online: http://www.geichina.org/_upload/ file/book/goingoutreport/Understanding_China\T1\textquoterights_Overseas_Investments_Governance_ and_Anyalsis\%20of_E\&S_Policies.pdf (accessed on 10 June 2019).

161. Meng, S. Following the Money: Chinese NGOs Overseas. China Dialogue. 20 September 2010. Available online: https://www.chinadialogue.net/article/show/single/en/3825-Following-the-money (accessed on 16 May 2019). 
162. Cheshmehzangi, A.; Xie, L.; Tan-Mullins, M. The role of international actors in low-carbon transitions of Shenzhen's International Low Carbon City in China. Cities 2018, 74, 64-74. [CrossRef]

163. Yan, K. Interview with Dr. Hu Tao on China's Overseas Investment Guidelines. International Rivers. 24 April 2013. Available online: https://www.internationalrivers.org/resources/interview-with-dr-hu-tao-on-china-soverseas-investment-guidelines-7944 (accessed on 16 May 2019).

164. Lau, Z.Z. Empowering SMEs through Belt and Road. The Malaysian Reserve. 20 February 2018. Available online: https://themalaysianreserve.com/2018/02/20/empowering-smes-belt-road/ (accessed on 16 May 2019).

165. Orestes, G.D.; Ryan, M. The Belt and Road Initiatives: Opportunities and Challenges for EU SMEs. EU-SME Centre and China-Britain Business Business Council, 2018. Available online: http://www.eusmecentre.org. cn/it/guideline/belt-and-road-initiatives-opportunities-and-challenges-eu-smes (accessed on 10 June 2019).

166. Green Finance Initiative. Greening the Belt and Road. City of London Corporation. 2017. Available online: http://greenfinanceinitiative.org/wp-content/uploads/2017/10/Greening-the-Belt-and-Road-English. pdf (accessed on 10 June 2019).

167. Cooley, A. The Emerging Political Economy of OBOR. Center for Strategic and International Studies, 2016. Available online: https://www.csis.org/analysis/emerging-political-economy-obor (accessed on 16 May 2019).

168. Hurley, J.; Morris, S.; Portelance, G. Examining the Debt Implications of the Belt and Road Initiative from a Policy Perspective; CGD Policy Paper No. 121; Center for Global Development: Washington, DC, USA, 2018; Available online: www.cgdev.org (accessed on 16 May 2019).

169. Tan-Mullins, M. Dancing to China's Tune: Understanding the Impacts of a Rising China through the Political-Ecology Framework. J. Curr. Chin. Aff. 2017, 3, 1-30. [CrossRef]

170. Iyer, R. Good News for India as North-South Trade Corridor Takes Shape. The Diplomat. 10 June 2017. Available online: https:/thediplomat.com/2017/06/good-news-for-india-as-north-south-trade-corridortakes-shape/ (accessed on 16 May 2019).

171. Cadier, D. The Geopolitics of Eurasian Economic Integration. London School of Economics. 2014. Available online: http://www.lse.ac.uk/ideas/Assets/Documents/reports/LSE-IDEAS-Geopoliticsof-Eurasian-Economic-Intergration.pdf (accessed on 16 May 2019).

172. Goodman, M.P.; Hillman, J.A. Is China Winning the Scramble for Eurasia? The National Interest. 21 August 2017. Available online: http://nationalinterest.org/feature/the-new-cold-war-was-never-inevitable-21994? page $=$ show (accessed on 16 May 2019).

(C) 2019 by the authors. Licensee MDPI, Basel, Switzerland. This article is an open access article distributed under the terms and conditions of the Creative Commons Attribution (CC BY) license (http://creativecommons.org/licenses/by/4.0/). 